\title{
The public trust doctrine and critical legal geographies of water in California
}

\begin{abstract}
:
Legal processes shape how water resources are allocated, regulated, distributed, and governed. This paper examines the public trust doctrine, a legal principle that addresses the state's role in governing natural resources by requiring states to manage certain bodies of water and their shorelines for the good of the public. The paper focuses on how the public trust doctrine has been used-- with varying degrees of success - to protect water bodies by contesting the diversion and transfer of water in California. The paper compares how the doctrine was applied in two cases: Mono Lake and the Salton Sea, two California lakes that have been threatened by water diversions and transfers. Advocates at Mono Lake successfully used the public trust doctrine for environmental protection, while public trust was an unsuccessful strategy at the Salton Sea. The paper examines issues of nonequilibrium ecosystems, natural versus artificial ecosystems, and wasteful versus reasonable uses of water.

By investigating why one case was deemed eligible for public trust protections while the other was not, this paper examines how discursive constructions of nature are embedded in and enacted by legal institutions and how these constructions of nature impact the implementation of legal protections of natural resources. In examining the use of the public trust doctrine in California, the paper examines both the potential and the limitations of the public trust in practice, showing how legal processes and institutions can be used to protect public interests in natural resources but also how particular environmental narratives are reinforced through these institutions.
\end{abstract}

Keywords: California; law; legal geography; political ecology; public trust doctrine; water 


\section{Introduction}

As the famous quote often (mis)-attributed to Mark Twain about water in the American West goes: "Whiskey is for drinking, water is for fighting over." The quote conjures up images of ranchers shaking fists at each other across a stream. The real fighting over water, however, often occurs in the legal arena - in courtrooms, boardrooms, offices, and capitol buildings. This paper examines the public trust doctrine, a legal doctrine requiring states to protect public interests in certain water resources. California has one of the strictest interpretations of the public trust doctrine in the U.S.- - but even given these strong protections, efforts to use the doctrine for ecosystem protection have run up against boundaries that limit its usefulness. In this paper I compare two California-based cases to investigate why one case was deemed eligible for public trust protections while the other was not. In doing so the paper examines how discursive constructions of nature are enacted by legal institutions, and how this impacts legal protections for certain natural resources.

Legal scholars have recently questioned how laws developed with an assumption of static ecosystems can best respond to contemporary understandings of ecosystems as dynamic, complex, and nonequilibrium (Craig, 2012; Doremus, 2010; Ruhl, 2012)—questions that political ecology can help address. Meanwhile, political ecologists are grappling with questions of privatization of commons and natural resource governance in a neoliberal era-questions involving legal dimensions that can be addressed through a better understanding of law (Andrews and McCarthy, 2014). In this paper I bring the approaches of political ecology and legal geography together to examine the public trust doctrine, a potentially powerful legal tool to protect common resources. Interrogating the doctrine through a geographic lens reveals insights on how law intersects with contemporary understandings of postnatural ecosystems, hybridity, and nonequilibrium ecosystems. By examining the public trust doctrine's potentials and shortcomings in a particular context, the paper contributes to a fruitful field of study that brings legal scholarship on resource management and environmental law into closer conversation with political ecology.

I compare two California cases in which the public trust doctrine was proposed as a way to contest water transfers and diversions. The cases, Mono Lake and the Salton Sea, are both saline lakes whose ecosystems were threatened by water transfers and diversions. I explore the similarities and differences in the lakes to show why the public trust doctrine was successfully leveraged at Mono Lake but not at the Salton Sea. The analysis is based on qualitative data collected between 2012 and 2015, including 35 in-depth interviews with lawyers, government agents, and community advocates involved in the cases of the Salton Sea and/or Mono Lake, attendance at board meetings and community forums, and review of legal documents related to the two cases. All names have been changed in this paper to protect participants' privacy.

In this paper, I first describe the public trust doctrine's history, then discuss literatures on critical legal geography, political ecology, and legal geographies of water. Next, I compare the application of the public trust in two cases of California lakes. I describe how the public trust doctrine was applied successfully in the case of Mono Lake but failed to gain traction in the case of the Salton Sea. I then discuss key differences between the cases to explore why these two cases had opposite outcomes, focusing on the California public trust doctrine's limitations in terms of nonequilibrium ecosystems and places viewed as 'artificial' in origin. The conclusion argues that while in practice the application of the public trust doctrine in California has served 
to reinforce particular constructions of nature, the public trust doctrine still holds promise as a legal principle under active renegotiation that requires state protection of certain natural resources.

\section{Water law and the public trust doctrine}

In the United States, water rights are use rights: a holder of water rights has the right to use water, but does not own the water in the same way that a car or a house might be owned (Hutchins, 1977; Sax et al., 2006). Water rights vary on a state-by-state basis and several systems are commonly practiced: under the riparian doctrine water rights are held by those who own land adjacent to a body of water (the system used in the wetter Eastern U.S. states), while under the prior appropriation doctrine water rights are allocated according to the principle of 'first in time, first in right' (the system used in most of the drier Western U.S. states - although some states including California use a hybrid of both systems).

Water is widely recognized as a public resource even within systems of private ownership of water rights (Sax, 1988; Wescoat, 1997). The riparian doctrine requires that water uses be 'reasonable' while the prior appropriation doctrine stipulates that water must be put to 'beneficial use' (typically defined as any agricultural, industrial, or domestic use) (Hutchins, 1977). A water right can be deemed invalid if it does not meet these conditions. The principles of 'reasonable' and 'beneficial' use of water point to water's important public role: a water user is never acting completely independently, but instead is using water in context of a broader society. While many other resources also have public aspects, this broader societal context is particularly important given water's material characteristics: water is a flow resource that travels over political boundaries, a transporter of disease and pollution, and a necessary input for agriculture and industry as well as an essential element of life itself (Bakker, 2012). Interpretations of what constitutes a reasonable, beneficial, or wasteful use of water are dependent upon changing social and historical contexts (Gray, 1989, 2004). For example, over the past 40 years,

environmentalism and environmental law have recognized a broader range of habitat and environmental functions of water as 'beneficial' (Tarlock, 2010). However, public water rights have legal traditions that date back much longer than modern-day environmental law-including the 1500-year-old legal tradition of the public trust doctrine (Sax et al., 2006).

The public trust doctrine is a legal principle with Roman origins (Wescoat, 1997) that seeks to preserve public interests in rivers, the sea, and tidal lands, originally for the purposes of fishing and navigation (Blumm and Wood, 2013; Sax et al., 2006). The public trust doctrine does not just grant public rights to water; it "addresses the responsibilities of the state in regulating the use of navigable waters and the lands beneath them" (Sax et al., 2006, p. 590). Under the public trust doctrine, the public is the beneficiary of a trust that is held by the state, and the state therefore holds the responsibility to manage that trust on behalf of its beneficiaries (Ryan, 2015).

The public trust can be traced back to the Roman emperor Justinian, who decreed in 535 AD: "By the law of nature these things are common to mankind - the air, running water, the sea and consequently the shores of the sea" (Wood, 2014, p. 126). The public trust doctrine was incorporated into English common law, which gave the sovereign ownership of "all of its navigable waterways and the lands lying beneath them 'as trustee of a public trust for the benefit of the people."' This law meant that lands under navigable waterways were held in trust by the 
state on behalf of the public. After the American Revolution, the responsibility of protecting sovereign lands submerged under navigable waterways was transferred to each of the thirteen new American states. As each subsequent U.S. state was formed, it took on the role of acting as trustee for the benefit of the public under the Equal Footing Doctrine, and took control of submerged lands under navigable waters upon obtaining statehood. In the United States the public trust doctrine is implemented on a state-by-state basis. Each state's implementation differs based on interpretations of navigability, extent of tidal waters, and the scope of the public trust (for example, whether or not it includes recreation or environmental protection in addition to traditional protections of fishing, navigation, and commerce) (Craig, 2010a).

The public trust doctrine raises broader questions of the meaning of the 'public interest.' According to Sax, while there are several approaches for understanding the basis for the doctrine, "the approach with the greatest historical support holds that certain interests are so intrinsically important to every citizen that their free availability tends to mark the society as one of citizens rather than of serfs" (Sax, 1970, p. 484) Certain rights and interests-- such as the public's right to fisheries and navigable waters-were historically considered important enough that any particular individual or group should not be allowed to control them. Sax notes that this same principle was used to justify the creation of national parks. The principle of the common good as a right that accompanies citizenship has roots in political philosophers such as Aristotle and Rousseau, both of whom recognized an idea of common good as a goal of government that is separate from individual benefit and requires active participation of citizens (Lee, 2013). The idea of public trust and common good thus run counter to a conceptualization that the goal of government is to create a framework for individuals to maximize their own interests in a liberal market context (Lee, 2013).

The public trust doctrine was first put to the test in the U.S. in the case of Illinois Central Railroad Co. v. State of Illinois in 1892. In this case, the state's ability to grant lakefront property to a private railroad company was limited because it was ruled a violation of the public trust. The public trust doctrine has been the subject of intense controversy in American law and has sparked debates regarding the competing values of natural resources as well as tensions between private and public interests (Wilkinson, 1989). Some legal scholars, lawyers, and advocates believe the concept of the public trust holds excellent potential for environmental protection and public access, and have argued for increased use of the public trust doctrine (Brown, 2006; Klass and Huang, 2009; Wood, 2014). Others are concerned that excessive use of the public trust doctrine could take away from private water rights (Johnson, 1980; Lazarus, 1985), or that the doctrine gives excessive power to judges who are not accountable to the public (Ryan, 2001). The public trust doctrine continues to evolve, although it has not been used in practice as extensively as advocates had once hoped for (Klass and Huang, 2009).

As a legal principle that speaks directly to the state's role and responsibility in governing natural resources and the commons (Dowie, 2003), the public trust doctrine holds interest for geographers, especially political ecologists. It has been applied in a number of different contexts to a range of topics of concern within political ecology, including water rights, public beach access, and protection of wetlands, wildlife, and parklands (Blumm and Wood, 2013). The history, application, and mechanisms of the public trust have been described and debated by legal scholars (Blumm and Wood, 2013; Brown, 2006; Craig, 2010a, b; Johnson, 1980; Robie, 2011; Sax, 1970; Sax et al., 2006; Wilkinson, 1989; Wood, 2014), but in comparison the public trust has received remarkably little attention from geographers. A few scholars within the social 
sciences have studied the public trust in relation to wildlife (Peterson et al., 2011) and the development of offshore aquaculture (Skladany et al., 2007). Anthropologist McCay's (1998) work on New Jersey oyster beds and property rights is perhaps the most thorough consideration of the public trust doctrine from a political ecology perspective. The public trust doctrine deserves wider attention from a geographic perspective. The public trust doctrine also raises critical contemporary issues of the state's role in protecting commons and natural resources. Political ecology and critical legal geography offer useful theoretical tools to expand and update literature on the public trust by studying how the doctrine has been used to legitimize certain environmental constructions, discourses, and narratives.

\section{Critical legal geography and political ecology}

The field of critical legal geography has developed over the last 20 years and has recently expanded in terms of scope and range of contributors (Braverman et al., 2014; Delaney, 2014). The goal of critical legal geography is to draw attention to the ways in which "space, law, and (in)justice are the means of the co-production of each other" (Delaney, 2015, p. 2). Critical legal geography takes as a starting premise the idea that law is not a closed domain separate from 'society' (Blomley, 2003a). Critical legal geographers focus on the co-constitution of law and space and place, and view law as relational, socially produced, spatial, and laden with power relations (Blomley, 2003a; Blomley, 1994). Law is conceptualized as socially and historically situated; it is simultaneously produced by social norms and is an active agent in producing space (Blomley, 1994). While many institutions and practices are involved in the production of space and place, law carries the explicit authority (backed by force) of the state, thus carrying particular weight in terms of reifying social discourses and narratives and translating ideas into material reality (Blomley, 2003b). Within socio-legal studies and legal geography, law is conceptualized as a process rather than a thing; legal geographers suggest that closer attentiveness to these processes of law can contribute to a better understanding of geographic topics of concern (Delaney, 2014).

Legal geographers as well as legal scholars outside of geography have drawn attention to the particular challenges of environmental law. Laws engaging with environmental issues must reflect not only societal norms and codes, but also scientific understandings of the nonhuman world, a project that becomes especially tricky as scientific understandings of the world change over time and previously-held assumptions become invalid (Tarlock, 2010). Legal scholars have begun to examine how law can handle changing environments under new norms of climate change (Craig, 2010a; Ruhl, 2010; Tarlock, 2012), and how law can adapt to new ecological theories of complexity and panarchy (Craig, 2012; Doremus, 2010; Ruhl, 2012). These struggles point to the challenges of handling dynamic, unpredictable, complex socio-ecological systems under legal infrastructures designed with an understanding of nature as static and separate from humans. Recent attention to the concept of the 'Anthropocene' highlights the ways in which humans are integrally entangled with the nonhuman world, renewing efforts to break down nature-society binaries (Collard et al., 2014). Changing understandings of how the nonhuman world works present challenges to law that engages with environmental issues.

Geography offers insightful tools to address questions of nature-society relationships and complexity of socio-ecological systems. Geographers have unpacked categories such as 'natural' 
versus 'artificial' to show how they are constructed (for example, see Braun and Castree, 2005; Cronon, 1996; Soper, 1995). Political ecology studies the relationships between environmental issues and the construction and production of nature, political economy, scale, and power relations (Blaikie and Brookfield, 1987; Robbins, 2004). Political ecologists engaging with poststructural theory and science studies have examined how ideas of 'nature' and 'the environment' are constructed and how certain forms of knowledge and knowledge production take on legitimacy (Escobar, 1996; Goldman et al., 2011). However, until recently much of political ecology scholarship has favored the study of informal and tacit human-environment relationships over the study of law (Andrews and McCarthy, 2014).

Law is highly relevant for the study of political ecology - and nature-society geography more broadly - as boundaries defining categories of 'nature' and 'society' are mediated and produced through legal institutions and practices (Delaney, 2001, 2003). Several geographers have worked to bring political ecology and legal geography into more explicit conversation with one another. For example, Delaney has written extensively on the social construction of nature through law (Delaney, 2003); Benson (2011) has studied competing legal frameworks in the governance of uranium mining in the U.S. West; and Andrews and McCarthy (2014) have examined the legal aspects of the political ecology of shale gas extraction in Pennsylvania. The study of water has been a primary area of bridging between legal studies and humanenvironment geography. Water resource law is a realm in which geography clearly matters: for example, the prior appropriation doctrine was developed in response to a mismatch between hydrologic and climatic realities and existing laws governing water rights (Thompson et al., 1997). Legal processes are important for water resource management because law carries statebacked legitimacy: as Jepson explains in her study of the legal processes used to delineate boundaries and water rights of low-income communities in Texas, "The legal process demarcates the boundaries of water politics because the law determines who holds legitimate power to organize, distribute, and manage a region's physical water resources" (Jepson 2012 p. 615). Legal processes are used in attempts by the state to increase legibility (Perramond, 2013), and as an arena for putting specific ideologies of property rights into practice (Emel, 1990; Emel and Roberts, 1995; Emel et al., 1992). Legal geographers demonstrate the importance of closely examining legal processes and institutions in order to understand how water resources are allocated, regulated, distributed, and governed.

In this paper I build upon work bridging legal geography and political ecology by examining the public trust doctrine, a legal principle that addresses the state's role and responsibility in governing water resources. I argue that the public trust doctrine holds considerable interest for geographers in the areas of political ecology and critical legal geography; a close examination of how the public trust doctrine has been practically applied can answer calls for closer engagement between these two fields. In the rest of the paper I explore how the public trust doctrine has been put into practice in California, which has one of the most extensive public trust doctrines in the United States.

\section{California's public trust doctrine in practice}

California is well-known for its tensions and conflicts over water resource management (Hundley, 1992; Reisner, 1993). The following cases highlight two examples of how the public trust doctrine has been used in California, focusing on the application of the doctrine within the 
boundaries of a single state since the doctrine is interpreted and implemented at the state level (Wilkinson, 1989). California's public trust doctrine is one of the most protective in the U.S. The doctrine made a resurgence in California along with the development of environmental law in the 1970s, when law professor Joseph Sax wrote an influential article arguing that the public trust doctrine could and should be expanded to include recreational and ecological values (Sax, 1970). Shortly after, the public trust was applied in the 1971 case Marks $v$. Whitney, which expanded California's public trust doctrine to encompass recreation and ecology alongside navigation, commerce, and fishing. The court emphasized that the doctrine is "sufficiently flexible to encompass changing public needs." Marks $v$. Whitney served as the basis for the successful implementation of the public trust doctrine in the Mono Lake case, National Audubon Society $v$. Superior Court. The Audubon case was seen as setting influential new precedent in the use of the public trust doctrine to challenge existing appropriative water rights and to provide protection for instream flow even in small bodies of water that did not meet the 'navigability' requirement (Ryan, 2015). However, when the Salton Sea, another large saline California lake, faced similar threats of decline because of water transfers, the public trust doctrine turned out to be unhelpful. The following sections detail the uses and limitations of the public trust in each of these cases.

\section{Mono Lake}

Mono Lake, located in Mono County in the Eastern Sierra Nevada Mountains in California, is a shallow lake approximately 70 square miles in size. Because the lake is in a closed basin, its only outflow is through evaporation and the lake is salty and alkaline. Mono Lake is known by birders for its thriving population of millions of migratory birds. It is known by tourists for its photogenic tufa towers-large calcium formations that tower over the lake, creating stunning panoramas with their reflections. It is also well known by lawyers and environmentalists as the site of a landmark case in successful environmental protection through the implementation of the public trust doctrine.

In 1940 the Los Angeles Department of Water and Power (LADWP) completed construction on an extension of the existing Los Angeles Aqueduct, diverting streams that flowed into Mono Lake in order to meet the water needs of the city of LA (Hart, 1996). With reduced inflow from the diversions, the lake's shoreline began to recede and salinity increased. The receding shoreline exposed fine dust sediment from the lakebed, causing dust storms and damaging air quality. Islands that served as important bird nesting habitat were joined to the mainland, allowing predators to access bird nests. The increasing salinity began to impact the lake's food chain. In the 1970s a second barrel of the aqueduct was installed and Mono Lake's inflow was cut off nearly completely, which caused the lake's decline to accelerate (Ryan, 2015).

In 1976 Stanford ecologist David Gaines began studying the lake's ecology and organizing around the plight of the lake (Mono Lake Committee, 2015; Winkler, 1977). Gaines formed the Mono Lake Committee in 1978, and worked to galvanize the interest of the public around the lake's predicament. In 1979 the National Audubon Society joined the newly-formed Mono Lake Committee to bring a lawsuit against the LADWP. The case went from the Superior Court of Alpine County to the California Supreme Court, where it took the name National Audubon Society v. Superior Court. In 1983 the court made a landmark decision: Mono Lake held important public trust values that must be protected, even if protection meant putting limits on 
prior appropriation water rights which had been previously treated as sacrosanct (Ryan, 2015; Wilkinson, 1989). The decision stated:

The state has an affirmative duty to take the public trust into account in the planning and allocation of water resources, and to protect public trust uses whenever feasible. Just as the history of this state shows that appropriation may be necessary for efficient use of water despite unavoidable harm to public trust values, it demonstrates that an appropriative water rights system administered without consideration of the public trust may cause unnecessary and unjustified harm to trust interests... The human and environmental uses of Mono Lake - uses protected by the public trust doctrine - deserve to be taken into account. Such uses should not be destroyed because the state mistakenly thought itself powerless to protect them.

The public trust decision was implemented in conjunction with a second set of lawsuits in 1984 over Fish and Game Codes 5937 and 5946, which required that sufficient waters flow around a dam to keep downstream fisheries in good condition. A population of trout lived in Rush Creek, one of Mono Lake's tributaries that had been diverted by LADWP, and lawyers successfully argued that the creek needed sufficient flow to keep the fishery viable. In 1994, the State Water Resources Control Board (SWRCB) released Decision 1631, which incorporated both the Audubon case as well as the Fish and Game lawsuits. In Decision 1631, the SWRCB decreed that LADWP must protect both fish and lake levels at Mono Lake by maintaining a certain amount of flow in tributary streams. The Mono Lake decision had several important legal consequences for California: it affirmed that the state must balance public trust obligations with appropriative water rights, and it also extended public trust protections beyond navigable waterways to include smaller waterways with hydrologic connections to navigable waters (Ryan, 2015).

Protecting fish and lake levels meant lowering the amount of diversions to about a third of the original diversions in order to maintain a mandated lake level (Mono Lake Committee, 2015). The amount of water that can be diverted to Los Angeles is tied to the lake level, so if the lake is higher, more water can be diverted, and if it is lower, more water must stay at Mono Lake. Mono Lake Committee is now active in implementing restoration programs and monitoring the health of the lake, and also hosts education and outreach programs. The lake is a popular tourist destination for birdwatchers, hikers, and travelers, and Mono Lake's name is often invoked with regards to the public trust doctrine as the quintessential example of its success.

\section{Salton Sea}

The Salton Sea, like Mono Lake, is a large saline lake in a closed basin. The lake, about 375 square miles in size, is located in Imperial County in inland Southern California. Like Mono Lake, is famous for hosting millions of migratory birds each year. However, the similarities end there. Whereas Mono Lake is a tourist destination with calendar-worthy panoramic views, the Salton Sea is often referred to as an 'accident' and is legally designated an agricultural sump. Geologically, the lake has periodically filled and dried up again numerous times as the Colorado River delta meandered. The Salton Sea's current form is a result of a mishap in 1905, when a project diverting Colorado River water for agricultural irrigation went awry, and the entire flow of the Colorado River rushed in to fill the below-sea-level Salton Sink for over a year. After its creation, the new lake was expected to dry up eventually from the lack of natural inflow, but 
because of continued inflows of Colorado River water running off from irrigated agricultural fields, the Salton Sea still exists (Cohen et al., 1999; DeBuys, 2001; Delfino, 2006).

The Salton Sea is now the largest lake in California. It is 35\% saltier than the ocean, and has become a highly productive ecosystem supported by nitrogen fertilizer running off from agricultural fields (Redlands Institute, 2002). The lake supports a vibrant array of wildlife, including over 400 species of birds and several endangered species. Migrating birds traveling along the Pacific Flyway rely particularly heavily on the lake since much of California's wetland habitat has disappeared as a result of development over the past century (Wilson, 2012).

In 1980 a local farmer with property adjacent to the Salton Sea was upset about rising shorelines (the opposite of today's problems of receding shorelines) due to excessive agricultural runoff water. He sued the Imperial Irrigation District (IID) for wasteful use of water, and the case came before the SWRCB. The SWRCB held hearings and issued their response in the form of Decision 1600 in 1984. The decision found IID in violation of California's constitutional article prohibiting wasteful or unreasonable use of water (Article X Section 2) and required that the IID take actions to improve water conservation. The IID requested reconsideration of the decision, but the SWRCB reconfirmed their decision with Order 84-12. One of the IID's arguments was that "the use of Colorado River water for maintenance of the Salton Sea fish, wildlife, and recreational uses constitutes a present beneficial use - not a misuse." The state responded that the "beneficial effect of the present quantity of IID inflow is outweighed by the adverse effect of the rising water level on surrounding property."

In the hearings the Salton Sea Fish and Wildlife Club raised the issue of the SWRCB's duty to protect the public trust, and argued that reducing inflow to the Salton Sea would violate this duty. The SWRCB responded in a footnote in Order 84-12:

The public trust doctrine is based upon the state's ownership of navigable waterways and underlying lands as trustee for the benefit of the people. Upon its admission to the Union in 1850, California acquired title as trustee to navigable waterways and underlying lands. No such title or public trust easement was acquired to the property underlying the present Salton Sea since the Sea was not created until 1905. Therefore, regardless of the extent to which the public trust doctrine may or may not apply to an artificial body of water, it is apparent that the doctrine does not justify continued inundation of property to which no public trust easement attaches. (SWRCB Order 84-12, footnote 1.)

In this passage the SWRCB clarifies that the public trust doctrine does not apply to the Salton Sea because the state does not own the land beneath the water. The lake did not exist when California became a state and thus became the trustee of all navigable waterways and submerged lands; without a public title the lake is not subject to the public trust doctrine (Pollak, 1989).

In accusing the IID of wasteful use of water the decision laid the groundwork for the water transfers that would occur in future decades. The Quantification Settlement Agreement, approved in 2003, limits the total amount of water that California receives from the Colorado River. One strategy to limit California's water use involves the market-based transfer of water from agriculture to urban San Diego. The market-based agriculture-to-urban water transfer aims to reduce 'wasteful' uses of water by implementing efficient irrigation technologies and fallowing fields. Urban consumers, who pay higher water rates, pay farmers for the 'saved' water. But the reduction of agricultural runoff, the main inflow source of the Salton Sea, is projected to have severe negative consequences for the lake and the surrounding region. As the 
lake's shorelines recede and salinity increases, wildlife habitat and air quality will deteriorate significantly (Cohen and Hyun, 2006). The costs of inaction in terms of public health impacts of declining air quality have been estimated to be as high as $\$ 37$ billion over the next 30 years (Cohen, 2014). Property values, agricultural productivity, and ecological values are also projected to decline.

The Salton Sea situation is in many ways similar to Mono Lake: a saline lake is drying up because water is being transferred to urban areas, creating negative impacts on air quality and ecosystem. The decline of the Salton Sea represents a threat that could significantly impact people, wildlife, and ecosystems in the region. After the Mono Lake success, advocates and lawyers proposed the use of the public trust doctrine at the Salton Sea in response to the water transfers (Pollak, 1989). But the Salton Sea was and is not eligible for protections under the public trust doctrine for several reasons, which the paper explores in the following section.

\section{Understandings of ecology and ideas of nature: Key differences}

When the Mono Lake Audubon decision came down from the courts, the legal community speculated that the public trust doctrine would become a highly influential tool for protecting ecological and recreational values in public lands and waters in California. However, in the subsequent case of the Salton Sea, a similar lake with similar benefits and potential harmful impacts, facing a similar threat of decline because of water diversions and transfers, the public trust doctrine was deemed inapplicable. In the following section I review several issues raised by the implementation and limitations of the public trust doctrine: first, the limitations of applying the public trust doctrine to nonequilibrium ecosystems; second, the doctrine's limited ability to address ecosystems constructed as 'artificial' or 'manmade;' and third, challenges of balancing different values around water.

\section{Nonequilibrium ecosystems}

The State Lands Commission holds authority over the sovereign lands owned by the state of California. When California became a state on September 9, 1850, the state acquired title to the lands submerged under navigable waters including lakes, navigable rivers, and tidal waters. According to the State Lands Commission's Public Trust Policy, these lands are held in trust for the people of California by the state, and cannot be bought and sold, but must be maintained for uses including fishing, navigation, and environmental preservation and recreation (California State Lands Commission, 2015).

Doug and Dave are two members of the State Lands Commission interviewed for this study. Asked about the Salton Sea, they explained why the lake is ineligible for public trust protections:

Dave: You know the history of Salton Sea there, right? That's why we don't own jurisdiction over it.

Doug: It's something that wasn't caused by nature, from the standpoint of being there in 1850 . But obviously, it has a lot of similarities [to Mono Lake]. It's saline. And it's a huge problem. It exists... runoff from agriculture, the toxics in it... 
Dave: It doesn't have the protections of the Public Trust.

Doug: It's the courts, again. It's the courts that look at these things... We, again, narrowly look at it from the land standpoint. Was it in 1850, a body of water that was navigable? And so forth. From our standpoint, we don't think that this agency has direct jurisdiction.

Although the rules may seem straightforward, in practice 'navigable waters' can be tricky to define (Craig, 2010b); for example, how does one prove a body of water was or was not navigable a hundred and fifty years ago? Doug comments on the difficulty of defining which bodies of water are under the jurisdiction of the State Lands Commission and which are not:

Doug: California doesn't have a whole lot of real, natural lakes. There aren't a whole lot of them. Most of our water bodies that are not rivers are reservoirs on rivers, which the State Lands Commission doesn't have jurisdiction over. Because the rivers that they block were not navigable. That what gets me about our jurisdiction. It's just, we don't have jurisdiction over all rivers. They have to be navigable, susceptible to commercial navigation the day of statehood, September 9, 1850. If you didn't have that-- and there's still lots of disputes over that as to which rivers and which lakes are owned by the state. There's still arguments.

The granting of public trust protection to submerged lands under waters that were navigable in 1850 raises the issue of how environmental laws can handle the realities of flux and change in a non-steady-state ecosystem, particularly in a region that experiences a great deal of climatic variability. The state of California and the broader Southwestern U.S. does not have steady and predictable precipitation. The Colorado River's course has historically moved and fluctuated a great deal. When water bodies experience gradual changes of shoreline (by erosion or accretion), property boundaries move along with that gradual change, but when river courses change suddenly - as was the case when the Salton Sea refilled in 1905-boundaries of property ownership do not change (Sax et al., 2006). It is estimated that between the years 700 and 1700, the basin that is home to what is now the Salton Sea filled up and emptied four times, creating the vast and temporary Lake Cahuilla, a much larger body of water than the current Salton Sea (Waters, 1983). When California became a state in 1850, though, the lake had been dry for 150 years. Thus the Salton Sea's underlying lands are not owned by the State Lands Commission, and the lake that exists today is ineligible for public trust protections. As John, a natural resources lawyer involved in the Mono Lake case, explained:

John: The problem, the difference between Mono Lake and the Salton Sea is that Mono Lake was a lake larger than it is now at the moment that California became a state, and the state at time of statehood immediately took title to all of the submerged lands in navigable lakes. And everyone concedes that Mono Lake was navigable at that time, and it still is of course, you can take a kayak out on Mono Lake, that's all you need for navigability.

Now the Salton Sea has an issue. In geologic history, as the Colorado River meanders to its mouth, the Colorado is named for having so much silt in its waters. Over geologic time the river channel flowing into the Sea of Cortez would get clogged, and the river would turn westward and downward and end up going into the Salton Sea. And so, for example, three or four hundred years ago, the Salton Sea might have looked somewhat similar to what it does now. It looks the way it looks now not just because of current inflow to it, but because primarily all that water escaped in 1905. And as far as we can tell, the Salton Sea would have filled back up to a mile wide. 
And so, unlike Mono Lake, where the state got the title to all the submerged lands, at the Salton Sea there is very little state ownership resulting from statehood. And so the public trust interest is considered a lot weaker there.

One of the great challenges of environmental law is accommodating recent shifts in scientific understandings of ecology towards a recognition that ecosystems are dynamic, unpredictable, and complex (Craig, 2012; Doremus, 2010; Ruhl, 2012). Nonequilibrium ecology, with its emphasis on flux and change over time, challenges traditional ideas of environmental conservation (Zimmerer, 2000). Environmental laws based on equilibrium ecology theories of the 1960s are becoming outdated in relation to more recent science (Tarlock, 1993). In the case of the Salton Sea, the lake's eligibility for public trust protections was based on the water level at a certain arbitrary point in history. The historically contingent use of the date of statehood as a baseline date for the public trust has had long-lasting legal impacts, illustrating the difficulties of assigning fixed legal status to complex, changing, nonequilibrium ecosystems.

\section{'Artificial' ecosystems and hybridity}

The case of the Salton Sea also brings up the issue of 'artificial' versus 'natural' ecosystems. In the 1989 case Golden Feather Community Association v. Thermalito Irrigation District, the California Court of Appeals ruled that the California public trust doctrine does not apply to 'artificial' bodies of water'. Thomas, a lawyer involved in the Mono Lake case, comments on the distinction between artificial and natural in the California public trust:

Thomas: It [the public trust doctrine] applies to navigable waters at the time of statehood and it continues to apply even if those navigable waters are modified subsequent to statehood... If it's an artificial lake, which the Salton Sea is, as a result of overflow of the Colorado River, then it doesn't apply.

Nature-society geographers have discussed at length the trouble with categories such as 'natural' versus 'artificial', and have pointed out that 'nature' and 'society' do not exist in tidy opposition to one another (see, for example, Braun and Castree, 2005; Cronon, 1996; Soper, 1995). Critical legal geographers have also discussed how tacit understandings of 'nature' often underpin legal claims (Delaney, 2003), and how certain interpretations of nature end up gaining legitimacy through legal institutions. Recent geographic scholarship refers to 'postnatural' conservation as a necessary feature of the Anthropocene (Collard et al., 2014).

Mono Lake embodies a common vision of a 'natural' place. It is photogenic, in a remote location, it hosts vast numbers of migratory birds, and it has been around for thousands of years. The Salton Sea, in comparison, is often labeled an 'accident' or even 'dead.' The lake's lack of public appeal is attributable both to its history (the lake's current form came about from an irrigation mishap in 1905) and also to its present condition - the lake often smells of rotten eggs as a result of high concentrations of sulfur dioxide, and it has been the site of large-scale bird and

\footnotetext{
${ }^{1}$ Other states such as Hawaii have ruled differently on the issue of artificial versus natural bodies of water. Hawaii's public trust is even more expansive than California's (Slade, 2008); for example, Hawaii extends public trust protections to groundwater under the logic that groundwater and surface water cannot be separated. In Hawaii's 2000 Waiahole case the courts ruled that the state's public trust protects Native Hawaiian water uses-- which would be considered appropriative water rights in other states (Ede, 2002).
} 
fish die-offs tied to eutrophic conditions. Sue, an environmental lawyer involved in the Salton Sea case, explained the differences:

Sue: I would've loved to be able to have the same visuals [at the Salton Sea] as at Mono Lake. Mono Lake is a very beautiful and seemingly relatively untouched landscape. And it is naturally occurring. The other problem we faced with the Salton Sea was that people argue that the Salton Sea was man-made. You know, it was there because there was a breach in the levee back in 1907 or whatever it was, and it caused the Colorado River to shift and flow into the Salton Trough for a few years before they got it under control. So it was an accident. That and it's stinky, and it was an ag water receptacle for however many decades. I mean, it's not a postcard. I mean, it can be. If you're standing far away and the sun is setting, it's officially beautiful and has a very dramatic setting, but, compared to a Lake Tahoe, or a Mono Lake? Ew.

However, neither of these designations of 'natural' and 'artificial' are as straightforward as they seem at first glance. At Mono Lake, protecting trout in the streams feeding into the lake was one of the key aspects of the Fish and Game Codes and Decision 1631-but, there are actually no native trout in the Mono Lake Basin. In the 1850s, settlers introduced the first trout to streams around the region. Thomas (a Mono Lake lawyer) explained:

Thomas: When California became a state in 1850, there were no fish in these creeks. Well, at least no trout... The Basque Shepherds who were initial settlers in the Eastern Sierras brought the trout with them. Basically in order to provide a supplement of food supply along with whatever wild game they killed. They initially stocked the creeks with trout, and then the California Department of Fish and Game also stocked the creeks, beginning in the early 1900s, for the purpose of recreational fishermen... All the fish were introduced.

Does it matter? No, because the Fish and Game Code Section 5937 says that, "The owner of any dam will release sufficient flow to maintain fish in good condition." It does not distinguish between native and non-native. That distinction was raised, but it doesn't have any legal consequence.

Lucy, a member of the State Water Board who previously worked with the Mono Lake Committee, further explained how non-native trout came to be so pivotal in protecting the lake's inflow:

Lucy: There was a Fish and Game Code that said, "If there are fish in the streams below a dam, the dam operators have to keep water in those streams to keep the fish alive."

Now, until about ' 83 , from the late '70s into ' 83 , there was no water in those streams because it was so dry. We had a drought in the late '70s into the early ' 80 s, so there was no water. Then it rained torrentially, huge, huge, huge amounts of rain, so much rain that the dams spilled. Of course, there's lots of trout, brown trout that had been introduced into the streams up above the dam.

Not below the dam, but above the dam. Those trout were in the dam and they spilled over the dam. [laughs] At that point, Cal Trout sued LADWP to maintain the streams below the dam, so that the trout can stay alive. Now, these are introduced species, they're not endangered. There are tons of them, and they're from Europe.

It's not necessarily a pretty story but it's an interesting story in looking at how the laws worked. 
The non-native, non-endangered trout were a significant part of making the case for the protection of the 'natural' ecosystem of Mono Lake and its surrounding streams.

Meanwhile, the Salton Sea, labeled 'artificial,' exists as part of a larger Colorado River Delta system that would migrate around over time, causing the Salton Sea to fill and empty over time. John, the lawyer involved in litigating Mono Lake, gave a different perspective of whether the Salton Sea should be considered 'natural':

John: The Salton Sea, it definitely is not totally natural in the sense that the Sea was created by the breach of an artificial barrier - but I would argue that the [Colorado] River would have flowed into the Salton Sea in 1905 whether the barrier was there or not. It wasn't strong enough to resist the flood. So you have to really treat all of that as natural, you know.

Upon closer examination both of these places are perhaps better understood as hybrids - neither purely 'natural' nor 'artificial' places. John explained the trickiness around distinguishing between natural and artificial bodies of water under the law:

John: In California, there is judicial authority that the public trust does not apply to artificial bodies of water. So if a lake is made by a dam or impoundment, it can't be treated the same as a natural lake. On the other hand, the California Supreme Court has ruled that there is very little in California, if anything, that can still be called natural because of our activities during the gold rush and doing farming operations. All those things over time have really changed our water landscape.

The concept of hybridity, which has been well-developed by science and technology studies scholars, notably Haraway and Latour, emphasizes the difficulties in drawing clear boundaries around realms such as human, nonhuman, culture, nature, technology, and society (Haraway, 1991; Latour, 2005). Geographers have found great use in the idea of places as cyborgs or assemblages co-constituted by social, natural, technological, human, and nonhuman elements, rather than as essentialized 'natural' or 'manmade' environments (Braun and Castree, 2005; Whatmore, 2006). The Salton Sea has been described as a cyborg (Rudy, 2005). The story of how Mono Lake's fish were introduced and then subsequently protected suggest that even a more natural-seeming place can also be understood as hybrid. Conceptualizing both of these places as hybrids challenges boundaries between 'natural' and 'artificial' that are enforced by legal principles including the public trust doctrine.

\section{A balancing act}

The California SWRCB holds responsibility for balancing all beneficial uses of water, including appropriative water rights and public trust values (Robie, 2011). As the SWRCB notes, "the difficulty comes in balancing the potential value of a proposed or existing water diversion with the impact it may have on the public trust;" the SWRCB "is charged with implementing the action which would protect the latter" (SWRCB, 2015).

The case of Mono Lake involved balancing multiple interests, as Tim, an author who has written extensively on California water explained:

Tim: Basically, they said that, yes, Mono Lake has been damaged and that must stop, but that doesn't mean that no water should go to Los Angeles. There is a need just to fill a societal 
requirement there, so there must be a balancing to try to accommodate both. That's why LA can still take some water.

At Mono Lake, the balancing act was not only about legal precedent - it was also a matter of public advocacy and public perceptions. Thomas, who was involved in litigating the Mono Lake case, explained the importance of public opinion in obtaining the court's ruling:

Thomas: To understand the legal perspective, you really have to understand that this is not just about legal efficacy, it's also about advocacy. The Mono Lake cases were won in part through public relations, in fact in much part of the public relations. David Gaines with his slide show and volunteers, elected officials who visited the Mono Lake, and it just eventually...by 1983, there was a groundswell of public support for restoring that lake as a truly unique place.

You see this in the opening paragraph of the Supreme Court's decision. It isn't about the law, it's about... they literally begin with a geography lesson. "Mono Lake is located in the Eastern Sierra just east of the Yosemite National Park." The justice who wrote that was in love with this place.

To understand these cases you really have to go beyond the legal perspective, you really have to dig into the political and social perspective.

An environmental lawyer involved in the Salton Sea explained the difficulties in arguing for a similar balancing of interests and values at the Salton Sea:

Sue: You know, we appeared before the water board and definitely argued the public trust piece, the public trust doctrine... We got some traction, like the 15 years of mitigation water, but the problem that we had with the public trust piece is that it requires a balancing by the Board [SWRCB]. And it's hard when the Department of Interior is threatening to cut off water for waste and unreasonable use by the Imperial Irrigation District, it's a lot of pressure, to balance that and rule in favor of wildlife.

The source of Salton Sea inflow-- excessive agricultural runoff — had already been determined to be wasteful, and therefore potentially in violation of the California constitution. The Salton Sea also lacked the visual appeal and public support of Mono Lake. These factors made it much more difficult to successfully argue that the Salton Sea's needs ought to be balanced with other societal water needs. The case illustrates how challenging and contentious it can be to balance environmental, agricultural, rural, and urban water uses in order to best protect "the" public interest in a state with diverse and contradictory public needs.

\section{Conclusions}

In legal terms the question of why Mono Lake was eligible for public trust protection while the Salton Sea was not has a straightforward answer: the Salton Sea's lakebed is not owned by the state of California because the Salton Sea did not exist in 1850; moreover the Salton Sea counts as an artificial lake, and artificial bodies of water are not eligible for public trust protections in California. Read through the lenses of political ecology and critical legal geography, the comparison raises more interesting issues around nonequilibrium ecosystems, distinctions between 'natural' and 'artificial,' and the state's responsibility in balancing multiple interests around natural resources. The inapplicability of the public trust doctrine to the case of the Salton Sea shows that California's public trust doctrine - one of the strongest in the United States - has 
not yet been adequately adapted to contemporary understandings of socioecological hybridity and flux.

The public trust doctrine is worth studying as a dynamic legal principle that directly engages with the role of the state in balancing, interpreting, and implementing different values around resources. Elizabeth, a water policy expert who previously served as director of the Mono Lake Committee, noted the potential of the doctrine:

Elizabeth: David Gaines had a great quote, he said it [the public trust doctrine] was like a glacier, it moves very slowly but cuts very deeply.

The public trust doctrine can potentially offer a powerful legal strategy to push back against privatization and deleterious environmental impacts on common resources. The public trust doctrine remains an active legal arena: for example, in California the public trust doctrine is currently being expanded to include groundwater, which gives new legal recognition of the hydrologic relationships between surface water and groundwater. The doctrine holds broad potential beyond water supply as well. Craig, for example, argues that because climate change presents a clear threat to water resources that are protected under the public trust, the doctrine could provide a tool for states to adjust private rights in response to climate change impacts on water resources (Craig, 2010a). Scholars have additionally noted that the original Codes of Justinian mention not only water resources, but also air. Conceivably the public trust doctrine could therefore be extended to protect atmospheric resources, providing a legal basis for limiting carbon dioxide emissions in order to combat climate change (Ryan, 2015; Wood, 2007).

Given the realities of anthropogenic climate change and ecosystem changes, geographers who are critically rethinking understandings of conservation in a postnatural world (Braverman, 2015; Collard et al., 2014; Lorimer, 2015) have an important opportunity to work together with legal scholars considering similar issues of ecosystem dynamism and flux in the law (Craig, 2012; Doremus, 2010; Ruhl, 2012). Along with legal scholars, political ecologists and nature-society geographers can provide insight into how legal precedents are based on particular understandings of nature and ecology, and how legal systems might be adapted to incorporate contemporary realities. Together, geographers and legal scholars can work to envision a legal system that can protect natural resources and the public trust in the Anthropocene. 


\section{$\underline{\text { References Cited: }}$}

Andrews, E., McCarthy, J., 2014. Scale, shale, and the state: political ecologies and legal geographies of shale gas development in Pennsylvania. Journal of Environmental Studies and Sciences 4 (1), 7-16.

Bakker, K., 2012. Water: political, biopolitical, material. Social studies of science 42 (4), 616623.

Benson, M.H., 2011. Mining sacred space: law's enactment of competing ontologies in the American West. Environment and planning A 44, 1443-1458.

Blaikie, P., Brookfield, H., 1987. Land degradation and society. Methuen.

Blomley, N., 2003a. From "what?" to "so what?": Law and Geography in retrospect. Law and Geography: Current legal issues 5, 17-34.

Blomley, N., 2003b. Law, property, and the geography of violence: the frontier, the survey, and the grid. Annals of the Association of American Geographers 93 (1), 121-141.

Blomley, N.K., 1994. Law, space, and the geographies of power. Guilford Press New York.

Blumm, M.C., Wood, M.C., 2013. The Public Trust Doctrine in Environmental and Natural Resources Law. Carolina Academic Press, Durham, North Carolina.

Braun, B., Castree, N., 2005. Remaking reality: nature at the millenium. Routledge.

Braverman, I., 2015. Wild Life: The Institution of Nature. Stanford University Press.

Braverman, I., Blomley, N., Delaney, D., Kedar, A., 2014. The expanding spaces of law: A timely legal geography. Stanford University Press.

Brown, C.N., 2006. Drinking from a Deep Well: The Public Trust Doctrine and Western Water Law. Fla. St. UL Rev. 34, 1.

California State Lands Commission, 2015. About the California State Lands Commission.

Cohen, M., 2014. Hazard's Toll: The costs of inaction at the Salton Sea. Pacific Institute, Oakland, CA.

Cohen, M.J., Hyun, K.H., 2006. Hazard: The Future of the Salton Sea with No Restoration Project. Pacific Institute, Oakland.

Cohen, M.J., Morrison, J.I., Glenn, E.P., 1999. Haven or hazard: The ecology and future of the Salton Sea. Pacific Institute for Studies in Development, Environment and Security.

Collard, R.-C., Dempsey, J., Sundberg, J., 2014. A Manifesto for Abundant Futures. Annals of the Association of American Geographers 105 (2), 322-330.

Craig, R.K., 2010a. Adapting to Climate Change: The Potential Role of State Common-Law Public Trust Doctrines. Vermont Law Review 34, 781-853. 
Craig, R.K., 2010b. A Comparative Guide to the Western States' Public Trust Doctrines: Public Values, Private Rights, and the Evolution Toward an Ecological Public Trust. FSU College of Law, Public Law Research Paper (369), 53-197.

Craig, R.K., 2012. Learning to Think About Complex Environmental Systems in Environmental and Natural Resource Law and Legal Scholarship: A Twenty-Year Retrospective. Fordham Envtl. L. Rev. 24, 87.

Cronon, W., 1996. The trouble with wilderness: or, getting back to the wrong nature. Environmental History, 7-28.

DeBuys, W.E., 2001. Salt Dreams: land and water in low-down California. UNMPress. com.

Delaney, D., 2001. Making nature/marking humans: law as a site of (cultural) production. Annals of the Association of American Geographers 91 (3), 487-503.

Delaney, D., 2003. Law and nature. Cambridge University Press.

Delaney, D., 2014. Legal geography I Constitutivities, complexities, and contingencies. Progress in Human Geography, 0309132514527035.

Delaney, D., 2015. Legal geography II Discerning injustice. Progress in Human Geography, 0309132515571725.

Delfino, K., 2006. Salton Sea Restoration: Can There be Salvation for the Sea. Pac. McGeorge Global Bus. \& Dev. LJ 19, 157.

Doremus, H., 2010. Endangered Species Act: Static Law Meets Dynamic World, The. Wash. UJL \& Pol'y 32, 175.

Dowie, M., 2003. In Law We Trust, Orion Magazine, Great Barrington, MA.

Ede, K.C., 2002. He Kanawai Pono no ka Wai (A Just Law for Water): The Application and Implications of the Public Trust Doctrine in In re Water Use Permit Applications. Ecology Law Quarterly 29 (2), 283-314.

Emel, J., 1990. Resource instrumentalism, privatization, and commodification. Urban Geography $11(6), 527-547$.

Emel, J., Roberts, R., 1995. Institutional form and its effect on environmental change: The case of groundwater in the southern High Plains. Annals of the Association of American Geographers 85 (4), 664-683.

Emel, J., Roberts, R., Sauri, D., 1992. Ideology, property, and groundwater resources: an exploration of relations. Political Geography 11 (1), 37-54.

Escobar, A., 1996. Constructing nature: elements for a poststructural political ecology, in: Peet, R., Watts, M. (Eds.), Liberation Ecologies: Environment. Development, Social Movements. Routledge, New York, pp. 46-68.

Goldman, M.J., Nadasdy, P., Turner, M.D., 2011. Knowing nature: Conversations at the intersection of political ecology and science studies. University of Chicago Press. 
Gray, B.E., 1989. In search of Bigfoot: The common law origins of article X, section 2 of the California constitution. Hastings Const. LQ 17, 225.

Gray, B.E., 2004. Dividing the Waters: The California Experience. Hastings W.-NWJ Env. L. \& Pol'y 10, 141-209.

Haraway, D.J., 1991. A Cyborg Manifesto: Science, Technology, and Socialist-Feminism in the Late Twentieth Century, Simians, Cyborgs, and Women: The Reinvention of Nature. Routledge, New York, NY, pp. 149-181.

Hart, J., 1996. Storm over Mono: the Mono Lake battle and the California water future. University of California Pr.

Hundley, N., 1992. The great thirst: Californians and water, 1770s-1990s. University of California Press.

Hutchins, W.A., 1977. Water Rights Laws in the Nineteen Western States. Natural Resource Economics Division, Economic Research Service, United States Department of Agriculture.

Johnson, R.W., 1980. Public Trust Protection for Stream Flows and Lake Levels. UC Davis L. Rev. 14, 233.

Klass, A.B., Huang, L.-Y., 2009. Restoring the Trust: Water Resources and the Public Trust Doctrine, A Manual for Advocates. Center for Progressive Reform.

Latour, B., 2005. Reassembling the social-an introduction to actor-network-theory. Oxford University Press.

Lazarus, R.J., 1985. Changing conceptions of property and sovereignty in natural resources: questioning the public trust doctrine. Iowa L. Rev. 71, 631.

Lee, S., 2013. Common Good, Encyclopaedia Brittanica Online.

Lorimer, J., 2015. Wildlife in the Anthropocene: Conservation after nature. University of Minnesota Press, Minneapolis.

McCay, B.J., 1998. Oyster wars and the public trust: Property, law, and ecology in New Jersey history. University of Arizona Press.

Mono Lake Committee, 2015. History of the Mono Lake Committee.

Perramond, E.P., 2013. Water governance in New Mexico: Adjudication, law, and geography. Geoforum 45, 83-93.

Peterson, M.N., Lopez, A., Mertig, A.G., Liu, J., 2011. Assessing Attitudes Toward Wildlife Ownership in United States-Mexico Borderlands. Society \& Natural Resources 24 (9), 962971.

Pollak, A., 1989. Salton Sea, IID, and the Public Trust Doctrine: Some Implications of Water Transfers from the Imperial Valley, The. Environs: Envtl. L. \& Pol'y J. 13, 23.

Redlands Institute, 2002. Salton Sea Atlas. ESRI Press, Redlands, CA.

Reisner, M., 1993. Cadillac desert: The American West and its disappearing water. Penguin. 
Robbins, P., 2004. Political ecology: A critical introduction. Blackwell, Malden, MA.

Robie, R.B., 2011. Effective Implementation of the Public Trust Doctrine in California Water Resources Decision-Making: A View From the Bench. UCDL Rev. 45, 1155.

Rudy, A.P., 2005. Imperial contradictions: is the Valley a watershed, region, or cyborg? Journal of Rural Studies 21 (1), 19-38.

Ruhl, J., 2010. Climate change adaptation and the structural transformation of environmental law. Environmental Law 40, 343.

Ruhl, J., 2012. Panarchy and the law. Ecology and Society 17 (3), 31.

Ryan, E., 2001. Public Trust and Distrust: The Theoretical Implications of the Public Trust Doctrine for Natural Resource Management. Envtl. L. 31, 477.

Ryan, E., 2015. The Public Trust Doctrine, Private Water Allocation, and Mono Lake: The Historic Saga of National Audubon Society v. Superior Ct. Environmental Law 45.

Sax, J.L., 1970. The public trust doctrine in natural resource law: Effective judicial intervention. Michigan Law Review, 471-566.

Sax, J.L., 1988. The Limits of Private Rights in Public Waters. Envtl. L. 19, 473.

Sax, J.L., Thompson, B.H., Leshy, J.D., Abrams, R.H., 2006. Legal Control of Water Resources: Cases and Materials, Fourth Edition. Thomson-West, St. Paul, MN.

Skladany, M., Clausen, R., Belton, B., 2007. Offshore aquaculture: the frontier of redefining oceanic property. Society \& Natural Resources 20 (2), 169-176.

Slade, D, 2008. The Public Trust Doctrine in Motion: Evolution of the Doctrine 1997-2008. PTDIM LLC, Bowie, MD.

Soper, K., 1995. What is nature?: culture, politics and the non-human. Blackwell Oxford.

SWRCB, 2015. The Water Rights Process. State Water Resources Control Board.

Tarlock, A.D., 1993. Nonequilibrium Paradigm in Ecology and the Partial Unraveling of Environmental Law, The. Loy. LAL Rev. 27, 1121.

Tarlock, A.D., 2010. Environmental law: then and now. Wash. UJL \& Pol'y 32, 1.

Tarlock, D., 2012. Takings, Water Rights, and Climate Change. Vermont Law Review (36), 731.

Thompson, G.L., Wije, C., Shelley, F.M., 1997. Geography, Environment, and American Law. University Press of Colorado, Boulder, CO.

Waters, M.R., 1983. Late Holocene lacustrine chronology and archaeology of ancient Lake Cahuilla, California. Quaternary Research 19 (3), 373-387.

Wescoat, J.L., 1997. Toward a modern map of Roman water law. Urban Geography 18 (2), 100105.

Whatmore, S., 2006. Materialist returns: practising cultural geography in and for a more-thanhuman world. Cultural geographies 13 (4), 600-609. 
Wilkinson, C.F., 1989. The Headwaters of the Public Trust: Some Thoughts on the Source and Scope of the Traditional Doctrine. Envtl. L. 19, 425.

Wilson, R.M., 2012. Seeking refuge: birds and landscapes of the Pacific flyway. University of Washington Press, Seattle.

Winkler, D.W., 1977. An ecological study of Mono Lake, California. Institute of Ecology, University of California.

Wood, M.C., 2007. Nature's trust: A legal, political and moral frame for global warming. BC Envtl. Aff. L. Rev. 34, 577.

Wood, M.C., 2014. Nature's trust: Environmental law for a new ecological age. Cambridge University Press, New York.

Zimmerer, K.S., 2000. The Reworking of Conservation Geographies: Nonequilibrium Landscapes and Nature-Society Hybrids. Annals of the Association of American Geographers, 356-369. 